\title{
ACRL actions, June 1984
}

\section{Highlights of the Annual Conference meetings of the ACRL Board of Directors.}

$\mathbf{T}$ he Board of Directors of the Association of College and Research Libraries met twice during the ALA Annual Conference in Dallas: on Saturday, June 23, 1984, and Tuesday, June 26, 1984.

\section{Activity Sections/Board relationship}

The Board accepted and endorsed portions of recommendations by the Task Force on Activity Sections/Board Relationship:

First, that membership on the ACRL Board of Directors (excluding the three officers and three exofficio positions) be reduced from eight to seven, these slots to be filled by election from paired nominations (staggered) as follows: one pair nomimated by ULS; one pair nominated by CLS; one pair nominated by CJCLS; two pairs nominated by the Activity Sections Council; two pairs nominated by the Chapters Council. This arrangement would effectively replace the current system of six members from the type-of-library sections, and one member each from the Activity Sections and Chapters Council. The Board then referred the recommendation to the Constitution and Bylaws Committee with the instruction that it be translated into appropriate constitutional language for adoption by the ACRL membership. As with all changes to the ACRL Constitution, this motion requires one more approval by the Board at the next Midwinter Meeting as well as ratification by ACRL membership.

Second, that each section be encouraged to appoint or elect a Board of Directors liaison officer who would be responsible for attending all meetings as an observer and who would receive a Board agenda at the same time as Board members.

A Task Force recommendation that each ACRL member be allowed to join any two sections of ACRL without surcharge was not approved. The
Board then disbanded the Task Force with thanks and voted to appoint a new Task Force to explore the issues raised by the proposal that was not passed.

\section{Association for Educational Communication and Technology}

The Board approved a motion to approach AECT on the setting up of a formal liaison in the form of a joint committee. The Community and Junior College Library Section was mentioned as the ACRL unit most likely to carry out the function.

\section{Audiovisual materials}

The Board endorsed the proposal of the Resources and Technical Services Division's Audiovisual Committee that an ad hoc interdivisional committee be established within ALA to promote Cataloging in Publication for audiovisual materials.

\section{Bibliographic Instruction Liaison Project}

The Board instructed the ACRL office staff to explore ways to provide office support for the activities undertaken by the BI Liaison Project Officer and to negotiate for continuation of the press kits.

\section{Budget and Finance Committee}

The Board approved the 1984-85 budget for ACRL and Choice submitted by the Budget and Finance Committee. (A summary of these budgets will appear in an upcoming issue of $C \mho R L N e w s$. 


\section{Planning Committee}

The Board endorsed and supported the planning process for ACRL described in the document "A Proposed Planning Process for the Association of College and Research Libraries" (this proposal appears on pp.396-401 of this issue of C $b R L$ News). The Board then approved the creation of a Strategic Planning Task Force, as recommended by the Planning Committee.

\section{Professional Association Liaison Committee}

The Board established a new standing committee, based on the recommendation of the Bibliographic Instruction Section and the Planning Committee, that will have a Board mandate to bring ACRL's many interests before other professional associations.

\section{Publications Committee}

The Board approved the recommendation of the Publications Committee that the Board will not act on any proposals for new ACRL publications or substantial revisions in current publications without first consulting the Publications Committee.

\section{Rare Books and Manuscripts Section}

The Board approved the RBMS request for a 1985 preconference on "Changing Values and Rarity" to be held in Chicago.

A request to establish an RBMS Award for Exhibition Catalogues was referred back to the RBMS Executive Committee.

\section{Research Development Committee}

The Board voted to establish an Ad Hoc Committee on Research Development that will work with existing groups to aid research.

\section{Standards and Accreditation Committee}

The Board rescinded the ACRL Guide to Methods of Library Evaluation issued in 1968, and approved a June 1984 edition of the ACRL Policies and Procedures Manual.

\section{Task Forces}

The Board approved extending the charge of the Task Force for the Support of New Committee Members and Committee Chairs until June 1986.

The Board also accepted the reports of the Task Forces on Library Schools and Academic Libraries, and on the Research Needs of Academic/Research Libraries, thanked the members for their work, and referred the reports to the ACRL Planning Committee to analyze and refer to the appropriate units.

The Task Force on Performance Measures recommended to the Board that ACRL support the development of a manual for the collection of performance measures for academic libraries and that an ACRL committee on performance measures be established to monitor work on the manual. The Board accepted the Task Force's report, referred it to the Planning Committee for comment, discharged the Task Force with thanks, and established an Ad Hoc Committee on Performance Measures for Academic Libraries.

\section{Academic or Research Librarian of the Year Award}

The Association of College and Research Libraries invites nominations for the Academic or Research Librarian of the Year Award, presented jointly by ACRL and the Baker \& Taylor Company. Anyone wishing to submit nominations should send the form on the following page to ACRL/ALA, 50 E. Huron St., Chicago, IL 606112795.

Recipients of the award since its inception in 1978 have been Keyes D. Metcalf and Robert B. Downs (1978); Henriette D. Avram and Frederick G. Kilgour (1979); Evan I. Farber (1980); Beverly P. Lynch (1981); William Budington (1982); Richard M. Dougherty (1983); and Richard D. Johnson (1984).

The Award Committee selects persons to receive the award in accordance with the following guidelines:

Purpose: To recognize an individual member of the library profession who is making an outstand- ing national or international contribution to academic or research librarianship and library development.

Criteria: Individuals nominated should have demonstrated achievements in such areas as:

1. Service to the organized profession through ACRL and related organizations.

2. Significant and influential research on academic or research library service.

3. Publication of a body of scholarly and/or theoretical writing contributing to academic or research library development.

4. Planning and implementing a library program of such exemplary quality that it has served as a model for others.

The nominee does not have to meet all of the above criteria.

Rules: The award shall be made each year at a time and place to be determined by the ACRL Board of Directors. Announcement of the award 


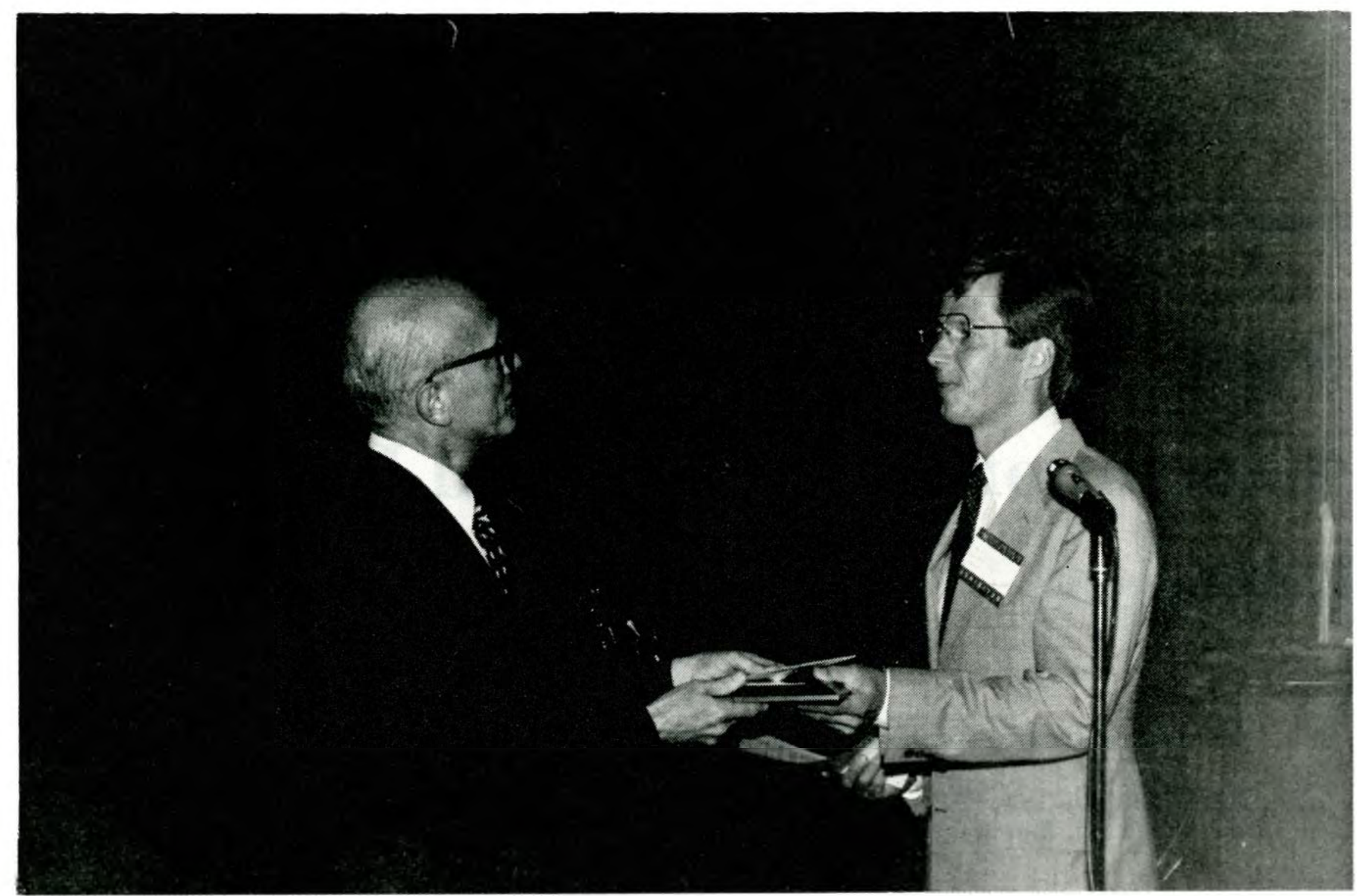

Richard Johnson receives the 1984 award in Dallas.

shall be made by the ACRL president at a time and place to be determined by the ACRL Board of Directors. If, in the opinion of the Award Committee, no worthy candidate is nominated in a given year, the award will not be presented that year.

Nominations: Nominations for the award must be returned to the chair of the Academic/Research Librarian of the Year Award Committee and must be postmarked no later than December 1, 1984. Nominations must be submitted in quintuplicate and should be accompanied by a statement of supporting reasons and a copy of the nominee's re- sume. Please do not solicit supporting letters seconding your nomination. Such letters will not be considered in the Award Committee's decision.

Nature of the award: The Academic or Research Librarian of the Year Award shall consist of $\$ 2,000$ and an appropriate citation.

The Award Committee for 1984 consists of the following persons: Patricia G. Oyler (chair), Associate Professor, Simmons College, Graduate School of Library and Information Science, 300 The Fenway, Boston, MA 02115; Cynthia B. Duncan, Dean of Library Services, Old Dominion Uni-

I nominate

(name and present address)

(Please list achievements of your nominee on a separate sheet.)

Nominated by

Address

Please return no later than December 1, 1984, to:

Academic or Research Librarian Award

Association of College and Research Libraries, ALA

50 East Huron Street

Chicago, IL 60611-2795 
versity, Norfolk, VA 23508; Elinor Ebeling, 228 Clubhouse Drive, Middletown, NJ 07748; David Kaser, 2402 Rock Creek Drive, Bloomington, IN 47401; William A. Moffett, Director of Libraries,
Oberlin College, Oberlin, OH 44074; Charles B. Osburn, Dean and University Librarian, Central Library, University of Cincinnati, University and Woodside, Cincinnati, OH 45221.

\title{
A proposed planning process for the Association of College and Research
}

\section{Libraries}

\author{
Prepared by the Ad Hoc Planning Process Subcommittee \\ Susan Klingberg, Chair \\ Keith Russell, Member
}

\section{ACRL's strategy for planning over the coming years.}

\begin{abstract}
A the the January 1983 ALA Midwinter Meeting, committee to develop a planning process for the Association. The Subcommittee first outlined the elements which the process or model should include. It should: a) produce a written plan to guide ACRL for at least five years; b) have a built-in mechanism for evaluation and feedback; c) accommodate periodic reviews and updating; and d) simplify (as well as codify) the work of the ACRL Planning Committee in carrying out its responsibilities.

The model proposed in this report is a strategic planning model. The strengths of strategic planning have been widely discussed in recent management literature. In his book Academic Strategy, George Keller discusses the advantages of this approach. He describes strategic planning as active rather than passive, responsive to changing conditions, competitive, decision-oriented, and participatory (Johns Hopkins, 1983, pp.143-148). Another distinctive characteristic of strategic planning is its emphasis on formulating and evaluating alternative strategies.
\end{abstract}

Together, this report and model constitute a "plan for planning" for ACRL. It should first be reviewed and revised by the Planning Committee before being more widely distributed within ACRL. Following review and revision, the Subcommittee recommends the appointment of an ACRL Strategic Planning Task Force. The Task Force would be responsible for coordinating the planning process and writing the resulting strategic plan. When this is accomplished, the ACRL Planning Committee would take over responsibility for implementation of the plan, as well as evaluation, periodic review, and updating.

\section{The planning process}

Accompanying this report is a schematic diagram or model of the proposed planning process (see p.397). This section provides additional information about the steps in the process. The purpose of each step is explained, and related issues to be considered are discussed. Wherever possible, an appropriate group or body is named to carry out 